\title{
Biosecurity Measures and Constraints Among Rural Poultry Farmers in Zamfara State, Nigeria
}

\author{
Abdurrahman Hassan Jibril ${ }^{1,}$ *, Muhammad Bashir Bello ${ }^{1}$, Sanusi Muhammad Bello ${ }^{1}$, \\ Yusuf Saheed $^{2}$, Fatima Muhammad Balla ${ }^{1}$ \\ ${ }^{1}$ Faculty of Veterinary Medicine, Usmanu Danfodiyo University, Sokoto Nigeria \\ ${ }^{2}$ Department of Veterinary Public Health and Preventive Medicine, Ahmadu Bello University, Zaria, Nigeria
}

Email address:

jibrilah50@yahoo.com (A. H. Jibril)

*Corresponding author

\section{To cite this article:}

Abdurrahman Hassan Jibril, Muhammad Bashir Bello, Sanusi Muhammad Bello, Yusuf Saheed, Fatima Muhammad Balla. Biosecurity Measures and Constraints Among Rural Poultry Farmers in Zamfara State, Nigeria. Animal and Veterinary Sciences.

Vol. 4, No. 4, 2016, pp. 47-51. doi: 10.11648/j.avs.20160404.11

Received: April 6, 2016; Accepted: April 18, 2016; Published: August 4, 2016

\begin{abstract}
Poor biosecurity and Newcastle disease continues to be a major constraint to rural poultry production system in Nigeria. This study was conducted among 200 poultry farmers in the state with the use of questionnaire to assess the level of biosecurity and constraints among rural poultry farmers in six Local Government Areas of Zamfara State, Nigeria. Information obtained from respondents showed that, only about $12 \%$ of the farmers practice combination of hand washing and footbath in their poultry pens as well. Only about $13 \%$ of the farmers most times clean their pens and $50 \%$ of the respondents dispose carcasses by refuse dumping. Newcastle disease is reported as the most common disease and the major clinical signs were greenish diarrhoea and twisting of neck. During outbreaks the most farmers preferred to slaughter $(42.5 \%)$, while the others treat (27.0\%) the birds with veterinary methods- Antibiotics (25.0\%), antiviral agents (4.0\%) and local remedies (33.0\%). Most of the respondents $(53.0 \%)$ sometimes clean their poultry pen. Finally, it concluded that, the low level of commercial poultry production in the study area might be due to poor practices by the farmers. So, it is recommended that, government should put program about training poultry farmers on biosecurity, disease prevention and the adoption of modern husbandry practices suitable for the traditional poultry production system.
\end{abstract}

Keywords: Biosecurity, Rural Poultry Farmer, Newcastle Disease, Zamfara State

\section{Introduction}

Biosecurity refers to all the management practices aimed at excluding or reducing the potential for the transmission and spread of diseases to animals, humans or an area initially free from the diseases causing agents [1]. Biosecurity is of much importance in poultry production in so much that the FAO based the classification of poultry production systems on the levels of biosecurity [2]. Strict biosecurity measures in addition to vaccinations are strategic prevention and control policies adopted to control some contagious poultry diseases, are not enough to control them under field conditions [3]. The village poultry are kept by over $90 \%$ of rural households as local assets [4]. In Nigeria, virtually every household in rural and peri-urban communities keeps poultry for meat, supplementary income and $\mathrm{f}$ or meeting a wide range of social obligations $[5,6]$.

Nigerian poultry population is estimated to be 137.6 million, with backyard poultry population constituting $84 \%$ (115.8 million) and 16\% (21.7 million) of exotic poultry [2]. The distribution of chicken population in Nigeria revealed that $84.5 \%$ of local chickens are found in the Northern state of the country. On the other hand, $83 \%$ of exotic breeds are found in southern part of the country [7]. Agricultural sector remains the largest contributor to the Nigerian economy, accounting for over $38 \%$ of the non-oil foreign exchange earnings, and employing about $70 \%$ of the active labour force of the population. The poultry sub-sector is the most commercialized of all the sub-sectors of the Nigeria's agriculture [2], with a higher percentage of this poultry raised 
for subsistence production [8]. This category of birds represents a significant part of Nigerian rural economy in particular and of the national economy as a whole and are kept under the extensive management system [9]. Flocks usually consist of cocks, Hens and chicks. In some households other poultry species are also kept in the same compound. Neighbouring flocks are allowed to mix freely and a cock may service several flocks [10]. This study was designed to assess the biosecurity and poultry production practices among rural poultry farmers in Zamfara State.

\section{Materials and Methods}

\subsection{Study Area/Study Population}

This study was carried out in six local government areas (Bungudu, Gusau, Talata- Mafara, Bakura, Kaura-Namoda and Zurmi) of Zamfara State, Nigeria. The study targeted rural and backyard poultry farmers in four selected local government of Zamfara State

\subsection{Questionnaire Design}

An open ended structured questionnaire was pretested and later administered to 200 respondents that engaged in backyard poultry production. Information about husbandry practices, biosecurity measures, sources of poultry, common diseases observed, disease preventive measures and methods of handling sick and dead birds were obtained. Data generated were exported to Statistical Package for Social Sciences (SPSS ${ }^{\circledR}$ ) version 17 (SPSS Inc. Chicago, IL., USA, 2008) and were analyzed, using descriptive statistics to calculate frequencies and percentages.

\section{Results}

The response rate to the questionnaires was $100 \%$ and comprised of poultry farmers from four local government areas of Zamfara State. About $65.5 \%$ of the respondents were male and $34.5 \%$ were female. Also, $23.5 \%$ of the respondents had no formal education, $4.5 \%$ had tertiary education, $55.5 \%$ were full time farmers and civil servants accounted for $11.5 \%$ of the respondents (Table 1). Only about $12 \%$ of the respondents use a combination of hand washing and footbath in their farms as preventive measures against poultry diseases, while about $69 \%$ of them do not use any of these measures (Table 2). Most of the respondents (53.0\%) sometimes cleaned their poultry pen, while $17.5 \%$ rarely cleaned their poultry houses (Table 3 ). When there was an outbreak of Newcastle disease most farmers (42.5\%) preferred to slaughter; $25.5 \%$ tended to apply local remedy, while $27.0 \%$ used veterinary treatment methods (Table 4 ). The most common poultry disease $(39.0 \%)$ was Newcastle disease as indicated by the respondents (Table 5). Major clinical signs that respondents noticed during outbreaks of Newcastle disease included greenish diarrhoea (32.0\%), twisting of neck $(20.0 \%)$, paralysis of legs and wings $(6.0 \%)$, nasal discharges (3.5\%) and swollen head 6.5\% (Table 6).

Treatment methods employed include administration of antibiotics $(25.0 \%)$ and local remedies $(33.0 \%)$ as shown in Table 7. Fifty per cent of the respondents disposed carcasses in refuse dumps, while $15.0 \%$ preferred to bury poultry carcasses (Table 8).

Table 1. Demographic distribution of poultry farmers by sex, educational status and occupation from four local government areas in Zamfara State, Nigeria.

\begin{tabular}{lll}
\hline Factor & Frequency $\mathbf{N}=\mathbf{2 0 0}$ & $\mathbf{\%}$ \\
\hline Sex & 131 & 65.5 \\
Male & 69 & 34.5 \\
Female & & \\
Educational qualification & 37 & 18.5 \\
Primary & 18 & 9.0 \\
Secondary & 9 & 4.5 \\
Tertiary & 89 & 44.5 \\
Others & 47 & 23.5 \\
None & & \\
Occupation & 19 & 9.5 \\
Student & 111 & 55.5 \\
Farmer & 23 & 11.5 \\
Civil servant & 32 & 16.0 \\
Trader & 15 & 7.5 \\
Others & & \\
\hline & & \\
\hline
\end{tabular}

Table 2. The use of Hand washing and Footbath in poultry house for the prevention of poultry diseases as indicated by respondents from local government's areas of Zamfara State.

\begin{tabular}{|c|c|c|c|c|c|c|}
\hline \multirow[t]{2}{*}{ Preventive measures } & \multicolumn{4}{|c|}{ Local government areas } & \multirow[t]{2}{*}{ Total } & \multirow[t]{2}{*}{$\%$} \\
\hline & Bakura & Bungudu & K/Namoda & Gusau & & \\
\hline & \multicolumn{4}{|c|}{ Number of respondents } & & \\
\hline Hand-washing & 7 & 3 & 8 & 10 & 28 & 14 \\
\hline Footbath & 1 & 0 & 3 & 5 & 9 & 4.5 \\
\hline Hand-washing and Footbath & 3 & 5 & 11 & 5 & 24 & 12 \\
\hline None & 39 & 42 & 28 & 30 & 139 & 69.5 \\
\hline Total & 50 & 50 & 50 & 50 & 200 & 100 \\
\hline
\end{tabular}


Table 3. Frequency of cleaning poultry houses/pen as indicated by respondents from local government areas of Zamfara State, Nigeria.

\begin{tabular}{|c|c|c|c|c|c|c|}
\hline \multirow[t]{2}{*}{ Frequency of cleaning } & \multicolumn{4}{|c|}{ Local government areas } & \multirow[t]{2}{*}{ Total } & \multirow[t]{2}{*}{$\%$} \\
\hline & Bakura & Bungudu & K/Namoda & Gusau & & \\
\hline & \multicolumn{4}{|c|}{ Number of respondents } & & \\
\hline Never & 5 & 10 & 11 & 6 & 32 & 16.0 \\
\hline Rarely & 17 & 7 & 3 & 8 & 35 & 17.5 \\
\hline Sometimes & 23 & 27 & 29 & 27 & 106 & 53.0 \\
\hline Most times & 5 & 6 & 7 & 9 & 27 & 13.5 \\
\hline Total & 50 & 50 & 50 & 50 & 200 & 100 \\
\hline
\end{tabular}

Table 4. Methods of handling sick chickens as indicated by respondents from local governments of Zamfara State, Nigeria.

\begin{tabular}{|c|c|c|c|c|c|c|}
\hline \multirow{2}{*}{$\begin{array}{l}\text { Method of handling } \\
\text { chickens }\end{array}$} & \multicolumn{4}{|c|}{ Local government areas } & \multirow[t]{2}{*}{ Total } & \multirow[t]{2}{*}{$\%$} \\
\hline & Bakura & Bungudu & K/Namoda & Gusau & & \\
\hline & \multicolumn{4}{|c|}{ Number of respondents } & & \\
\hline Removal from flock & 5 & 2 & 0 & 1 & 8 & 4.0 \\
\hline Veterinary treatment & 7 & 9 & 15 & 23 & 54 & 27.0 \\
\hline Local treatment & 19 & 15 & 9 & 7 & 50 & 25.0 \\
\hline Slaughter & 17 & 24 & 26 & 18 & 85 & 42.5 \\
\hline Do nothing & 3 & 0 & 0 & 0 & 3 & 1.5 \\
\hline Total & 50 & 50 & 50 & 50 & 200 & 100 \\
\hline
\end{tabular}

Table 5. Common poultry diseases as reported by respondents from four local government areas of Zamfara State, Nigeria.

\begin{tabular}{|c|c|c|c|c|c|c|}
\hline \multirow[t]{2}{*}{ Disease } & \multicolumn{4}{|c|}{ Local government areas } & \multirow[t]{2}{*}{ Total } & \multirow[t]{2}{*}{$\%$} \\
\hline & Bakura & Bungudu & K/Namoda & Gusau & & \\
\hline & \multicolumn{4}{|c|}{ Number of respondents } & & \\
\hline Newcastle disease & 15 & 21 & 23 & 19 & 78 & 39.0 \\
\hline Infectious bursal disease & 9 & 3 & 7 & 6 & 25 & 12.5 \\
\hline Ectoparasitism & 5 & 2 & 1 & 9 & 17 & 8.5 \\
\hline Coccidiosis & 7 & 7 & 11 & 7 & 32 & 16.0 \\
\hline ND, IBD and coccidiosis & 5 & 11 & 3 & 0 & 19 & 9.5 \\
\hline Fowl pox & 3 & 1 & 4 & 4 & 12 & 6.0 \\
\hline All of the above & 6 & 5 & 1 & 5 & 17 & 8.5 \\
\hline Total & 50 & 50 & 50 & 50 & 200 & 100 \\
\hline
\end{tabular}

$\mathrm{ND}=$ Newcastle disease

$\mathrm{IBD}=$ Infectious bursal disease

Table 6. Major clinical signs of Newcastle disease as indicated by respondents from four local government areas of Zamfara State, Nigeria.

\begin{tabular}{|c|c|c|c|c|c|c|}
\hline \multirow[t]{2}{*}{ Clinical signs } & \multicolumn{4}{|c|}{ Local government areas } & \multirow[t]{2}{*}{ Total } & \multirow[t]{2}{*}{$\%$} \\
\hline & Bakura & Bungudu & K/Namoda & Gusau & & \\
\hline & \multicolumn{4}{|c|}{ Number of respondents } & & \\
\hline Swollen head only & 3 & 5 & 0 & 5 & 13 & 6.5 \\
\hline Nasal and ocular discharges only & 2 & 0 & 2 & 3 & 7 & 3.5 \\
\hline Greenish diarrhoea only & 13 & 21 & 19 & 11 & 64 & 32.0 \\
\hline Paralysis of legs or wings & 4 & 0 & 3 & 5 & 12 & 6.0 \\
\hline Twisting of neck only & 15 & 9 & 7 & 9 & 40 & 20 \\
\hline All above signs & 2 & 4 & 3 & 0 & 9 & 4.5 \\
\hline Total & 50 & 50 & 50 & 50 & 200 & 100 \\
\hline
\end{tabular}

Table 7. Treatment methods employed during outbreak of Newcastle disease as indicated by respondents from four local government areas of Zamfara State, Nigeria.

\begin{tabular}{|c|c|c|c|c|c|c|}
\hline \multirow[t]{2}{*}{ Method of treatment } & \multicolumn{4}{|c|}{ Local government areas } & \multirow[t]{2}{*}{ Total } & \multirow[t]{2}{*}{$\%$} \\
\hline & Bakura & Bungudu & K/Namoda & Gusau & & \\
\hline & \multicolumn{4}{|c|}{ Number of respondents } & & \\
\hline Antibiotics & 13 & 7 & 11 & 19 & 50 & 25.0 \\
\hline Vaccines & 0 & 0 & 0 & 2 & 2 & 1.0 \\
\hline Antiviral & 0 & 0 & 3 & 5 & 8 & 4.0 \\
\hline Local concussion & 12 & 23 & 19 & 12 & 66 & 33.0 \\
\hline Antibiotics and Antiviral & 0 & 0 & 3 & 7 & 10 & 5.0 \\
\hline Local concussion and antibiotics & 25 & 20 & 14 & 5 & 64 & 32.0 \\
\hline Total & 50 & 50 & 50 & 50 & 200 & 100 \\
\hline
\end{tabular}


Table 8. Methods of disposal of carcasses as indicated by respondents from local government areas of Zamfara State, Nigeria.

\begin{tabular}{lllllll}
\hline Method of carcass disposal & Local government areas & & Total & \% \\
\hline & Bakura & Bungudu & K/Namoda & Gusau & \\
\hline & Number of respondents & & & & \\
\hline Bury & 3 & 7 & 9 & 11 & 30 & 15.0 \\
Burning & 9 & 13 & 6 & 13 & 41 & 20.5 \\
Refuse dumping & 29 & 21 & 31 & 19 & 100 & 50.0 \\
Consumption & 0 & 2 & 0 & 0 & 2 & 1.0 \\
Burning and refuse dumpings & 9 & 7 & 4 & 7 & 27 & 13.5 \\
Total & 50 & 50 & 50 & 50 & 200 & 100 \\
\hline
\end{tabular}

\section{Discussion}

The major economic activity of the people of Zamfara State is farming and this engages by over $90 \%$ of the population. The poultry industry is characterized majorly by backyard, small scale-medium scale commercial production system and a growing area of large commercial system. Majority of the respondents were male $(65.5 \%)$ followed by female $34.5 \%$. This is because most of the women in the study area engaged in rearing small ruminants, while the male engaged in cattle and poultry production. This is consistent with the work of [11] that reported $65.3 \%$ male and $34.7 \%$ female ownership of local chickens. However some reports showed that the poultry industry in the rural areas is largely in the hands of women and children as they own or manage the rural poultry $[12,13,14]$. Sanitation is poor, as greater majority of poultry farmers do not have footbath or hand washing provisions in their poultry facilities. These have serious implications on the spread of contagious poultry diseases by people as well as being of public health importance regarding zoonoses such as highly pathogenic avian influenza. Most of the rural poultry farmers dispose of dead birds at refuse dumps By implication, this may lead to the spread of infection to wild birds, domestic free roaming birds, cats and dogs by feeding on these dead birds, thereby encouraging the spread of infections to both humans and animals. During the dry season, dust can be a problem due to accumulated dry faeces and fine dust aerosols which could easily transmit airborne respiratory diseases or cause stress to the respiratory mucosa of birds housed in such premises. Lack of cleaning and hygiene could predispose birds to external parasites, which cause harm, discomfort, stress and act as intermediate hosts for various diseases [15]. On the other hand, accumulated faeces in unclean premises with a lack of ventilation could result in ammonium toxicity during the humid wet season, causing impairment of the respiratory system and predisposing birds to infectious respiratory diseases like ND, infectious laryngotracheitis, infectious bronchitis, infectious coryza and Mycoplasma infections. Furthermore, E. coli could gain entry through the damaged respiratory mucosa. Such lack of proper management could contribute to the fact that ND is endemic and persistent in village poultry.

The most common poultry disease as indicated by the respondents was Newcastle disease. The major clinical signs of Newcastle disease were greenish diarrhoea, twisting of neck, paralysis of legs and wings, nasal discharges and swollen head. These clinical signs are in agreement with (16) reported that the clinical signs and the speed at which the signs appear vary widely and depend upon infectivity and dose of virus, the species, age and immune status of the host, environmental conditions and the route of exposure.

The results of this study revealed, most farmers use traditional remedies to treat sick birds. This agreed with the works of [17] observed that, the traditional remedies are reported to be much easily and readily obtained and affordable by rural livestock farmers. Also, [11] stated that, the majority of the rural chicken farmers $(53.2 \%)$ used ethnoveterinary medicines for the management of chickens suffering from ND [18] stated that ethnoveterinary therapy featured as the most frequent method of disease control, in conjunction with slaughter (eating) and selling among rural poultry in Cameroon and Nigeria where the principal cause of chicken loss has been attributed to disease and predation. [19] reported that ethnoveterinary practices were common in rural poultry production because of the almost complete absence of assistance from extension services and the ease and low cost of acquiring ethnoveterinary substances though such method of therapy is associated with very little success and their efficacy requires further investigation. The practice of sourcing for medicament through the use of traditional method of medicare for treatment of birds is not enough to ensure good health of the birds due to poor knowledge and understanding of the aetiology and pathology of poultry diseases by poultry farmers [20]. They may therefore succeed in treating the observable symptoms of the disease without dealing with the actual cause.

\section{References}

[1] Halifa, M. (2008). Good biosecurity practices in nonintegrated commercial and in scavenging production systems in Tanzania. FAO Study report., 1-28.

[2] Adene, D. F. \& Oguntade, A. E. (2006). The structure and importance of the commercial and rural based poultry industry in Nigeria. FAO (Rome) study, October, 1-70.

[3] Abdu PA (2007). Manual of Important Poultry Diseases in Nigeria (2 ${ }^{\text {nd }}$ edition). MacChin Multimedia Designers, Samaru-Zaria., 1-100. 
[4] Ndegwa, J. N., Norrish, P., Mead, R., Kimani, C. W. and Wachira, A. M. (2000). A research process and methodology focusing on indigenous Kenyan chickens, In: Proceedings of the International Network for Family Poultry Department Symposium. XXI World's Poultry Congress, Montreal Canada, 20-24 August, 3-12.

[5] Dafwang, I. I. (1990). Rural poultry production in Nigeria, $A$ Report Prepared for the Presidential Task Force on Alternative Formulations of Livestock Feeds (Task Force 11: Product Development, Quality Evaluation and Health Implications, Pp 50. Ed. McGraw-Hill, New York, U.S.A., 399.

[6] Sonaiya, E. B. and Olori, V. E. (1990). Family poultry production in South Western Nigeria In: Rural poultry production in Africa (Sonaiya, E. B. Ed.). Proceedings of International Workshop held on November 13-16 1989 at Obafemi Awolowo University, Ile Ife, Nigeria, 27-29.

[7] Majiyagbe, K. A. and Lamorde, A. G. (1997). Nationally coordinated research programme on Livestock disease; subsectoral goals, performance and medium term research plan. Tropical Veterinarian, 15: 75-83.

[8] Federal Ministry of Agriculture and Rural Development, Federal Department of Livestock and Pest Control Services, Highly Pathogenic Avian Influenza Standard Operating Procedures, February 2006.

[9] Ajala, M. K., Nwagu, B. I. and Osuhor, C. U. (1997). Socioeconomic of free-range guinea fowl production among agropastoral Fulani women in Giwa L. G. A of Kaduna state, Nigeria. International Journal of Tropical Agriculture, (15): 37-44.

[10] Sa'idu, L., Bisalla, M. and Moumuni, M. (2006). Response of local breeds to challenge with Newcastle disease virus (Kudu 113 strain). Journal of Animal and Veterinary Advances, 5(11): 955-979.

[11] Musa, U., Abdu, P. A., Dafwang, I. I., Umoh, J. U., Saidu, L., Mera, U. M and Edache, J. A. (2009). Seroprevalence, seasonal occurrence and clinical manifestations of Newcastle disease in rural household chickens in Plateaus State, Nigeria, International Journal of poultry Science, 8(2): 200-204.

[12] Kitalyi, A. J. (1998). Village chicken production systems in rural Africa. Rome, Food and Agriculture Organization of the United Nations, FAO,. Animal Production and Health Paper No. 142, Rome, Italy, 1-81.

[13] Nwanta, J. A., Umoh, J. U., Abdu, P. A., Ajogi, I. and AlliBalogun, J. K. (2006) Management of losses and Newcastle disease in rural poultry in Kaduna State, Nigeria. Nigerian Journal of Animal Production, 33: 274-285.

[14] Sonaiya, E. B. (2007). Family poultry, food security and the impact of HPAI. World's Poultry.

[15] Wakawa, A. M. (2012). Surveillance and evaluation of risk factors for the occurrence and spread of avian influenza in Kano State, Nigeria. Ph.D Dissertation, Ahmadu Bello University, Zaria., 95-103.

[16] Alexander, D. J. (1997). Newcastle diseases and avian paramyxoviridae infection. In: Diseases of poultry, tenth edition, cabnet. B. W., Barnes, H. J., Beard, C. W., McDougald, I. R., Saif, Y. M. editors, 541-570.

[17] Abdu, P. A., Saidu, L. and George, B. D. J. (2000). Diseases of local poultry in Nigeria. Discovery and Innovation, 14: $107-118$

[18] Ambali, A. G., Abubakar, M. B. and James, T. E. (2003). An assessment of poultry health problems in Maiduguri, Borno State, Nigeria: Tropical. Veterinarian, 21(3): 138-145.

[19] Ekue, F. N., Pone, K. D., Mafeni, M. J., Nfi, A. N. and Njoya, J. (2002). Survey of the traditional poultry production system in the Bameda area, Cameroon In: Characteristics and Parameters of Family Poultry Production in Africa, FAO/IAEA, Vienna, Austria, 15-25.

[20] Nwanta, J. A. (2003). Field vaccination trials with Newcastle disease vaccine (NDV4HR) in local chicken in Kaduna State, Nigeria: Ph.D. Dissertation, Ahmadu Bello University, Zaria, Nigeria, 60-79. 